\title{
$\mathrm{Mg} / \mathrm{Cu}$ 超積層体の初期水素化過程における競合反応による微 細構造生成機構の解明*1
}

\author{
田中孝治 $1, * 2$ 近藤亮太 ${ }^{2}$ 竹下博之 2
}

\author{
1 国立研究開発法人産業技術総合研究所電池技術研究部門 \\ 2 関西大学化学生命工学部
}

J. Japan Inst. Met. Mater. Vol. 85, No. 6 (2021), pp. 213-222

(c) 2021 The Japan Institute of Metals and Materials

\section{Elucidation of Microstructure Formation Mechanism through Competitive Reactions during Initial Hydrogenation in $\mathrm{Mg} / \mathrm{Cu}$ Super-Laminate Composites}

\author{
Koji Tanaka ${ }^{1 * 2}$, Ryota Kondo ${ }^{2}$ and Hiroyuki T. Takeshita ${ }^{2}$ \\ ${ }^{1}$ Research Institute of Electrochemical Energy, National Institute of Advanced Industrial Science and Technology (AIST), Ikeda 563-8577 \\ ${ }^{2}$ Faculty of Chemistry, Materials and Bioengineering, Kansai University, Suita 564-8680
}

\begin{abstract}
Microstructure formation mechanism through competitive reactions during initial hydrogenation in $\mathrm{Mg} / \mathrm{Cu}$ super-laminate composites (SLCs) was investigated. $\mathrm{Mg} / \mathrm{Cu}$ SLCs $\left(\mathrm{Mg}_{2} \mathrm{Cu}\right.$ composition) were fabricated by accumulative roll bonding (ARB) and composed of laminate structures of $\mathrm{Mg}$ and $\mathrm{Cu}$ layers with the thickness of few hundreds nm. During the heating process of initial hydrogenation of $\mathrm{Mg} / \mathrm{Cu} \mathrm{SLCs}$, hydrogenation of $\mathrm{Mg}$ and alloying of $\mathrm{Mg}$ with $\mathrm{Cu}$ followed by hydrogenation of $\mathrm{Mg}_{2} \mathrm{Cu}$ occurs competitively. It is found that microstructures of $\mathrm{Mg} / \mathrm{Cu}$ SLCs during initial hydrogenation have changed drastically depending on the order of hydrogenation of $\mathrm{Mg}$ and $\mathrm{Mg} \mathrm{Cu}_{2} \mathrm{The}$ microstructures of $\mathrm{Mg} / \mathrm{Cu}$ SLCs after initial hydrogenation can be categorized in three types such as (1) $\mathrm{MgCu}_{2}$ network, (2) $\mathrm{MgCu}_{2}$ sheath and (3) $\mathrm{MgCu}_{2}$ layer. Features of differential scanning calorimetry (DSC) profiles of the first cycle were well explained by this microstructure formation mechanism. In order to achieve only $\mathrm{MgCu}_{2}$ network structure, it is important to get fine, even and uniform microstructures in $\mathrm{Mg} / \mathrm{Cu}$ SLCs. The large number of ARB cycles is inefficient to achieve the microstructures. Changing flow properties such as annealing during ARB, warm-rolling and ultrasonic assisted rolling can be good strategies for that purpose. [doi:10.2320/jinstmet.J2021011]
\end{abstract}

(Received February 18, 2021; Accepted March 4, 2021; Published April 23, 2021)

Keywords: microstructure formation mechanism, competitive reactions, initial hydrogenation, super-laminate composites, accumulative roll bonding, differential scanning calorimetry, activation energy, growth rates

\section{1. 緒言}

持続可能な社会の構築のためには, 地球温暖化の問題を解 決することが極めて重要であり, 低炭素化は, 地球温暖化対 策の最も重要な課題の 1 つである。そして, $\mathrm{CO}_{2}$ 放出削減の ためには，化石燃料に代わって再生可能なクリーンエネル ギーを使用することが有効である。中でも, 水素エネルギー は，最も将来性のあるクリーンエネルギーの1つである。し かしながら，水素をクリーンエネルギーとして利用するため には，水素を安全で使いやすい形で貯蔵する革新的技術を開 発することが必須である。

マグネシウムは, $\mathrm{MgH}_{2}$ の形で可逆的に $7.6 \mathrm{mass} \%$ の高容

\footnotetext{
*1 Mater. Trans. 60 (2019) 642-651 に掲載. Fig. 1 と Fig.9 のキャプ ションを Reflected electron から Backscattered electron に修正. Fig. 2 のキャプションの末尾に, of $\mathrm{Mg} / \mathrm{Cu}$ SLC in hydrogen atmosphere を 追加.

*2 現在 : 産業技術総合研究所先進パワーエレクトロニクス研究センター (Present address: Advavanced Power Electronics Research Center, National Institute of Advanced Industrial Science and Technology (AIST) )
}

量の水素貯蔵能を持ち ${ }^{1,2}$, 低コスト, 軽量, 資源量も豊富で あることから，水素貯蔵材料の有力な候補であると考えられ ている。しかしながら， $\mathrm{MgH}_{2}$ の標準生成エンタルピーが $-74 \mathrm{~kJ}\left(\mathrm{~mol} \mathrm{H}_{2}\right)^{-1}$ と熱的に安定であるため， $573 \mathrm{~K}$ を超える高 温でさえ水素吸蔵・放出速度が低く, その利用に限度がある 結果となっている ${ }^{3)}$. これらの弱点を克服するため, この数 十年間, 適切な金属と $\mathrm{Mg}$ の合金化 ${ }^{4-6)}$, 触媒添加 ${ }^{7-11)}$, ナノ 結晶粒子化 ${ }^{12,13)}$ など多くの努力がなされてきた．特に，メカ ニカル・アロイイングで作製された $\mathrm{Mg}-\mathrm{Ni}$ 基水素貯蔵合金か らは, 強加工により水素吸蔵・放出反応速度が改善するとい う将来性のある結果が得られた14-16)。しかしながら，この合 成プロセスはかなり費用が掛かる上に大量生産が容易ではな い17)。それゆえ，金属水素化物をより効率的に作製する新し い方法を確立するために尽力することが重要である。このよ うな観点から, 冷間圧延は興味深い代替法と思われる。なぜ なら，このプロセスは，単純で低コスト，大量生産化が容易 で工業的によく知られた手法であるからである。

Ueda らは, $\mathrm{Mg}-\mathrm{Ni}$ 基水素貯蔵合金の作製と水素化に繰り 返し圧延法 (accumulative roll bonding, ARB) が有効であるこ とを示した ${ }^{18)}$. それ以来, $\mathrm{ARB} て ゙$ 作製された $\mathrm{Mg}-\mathrm{Cu}^{19,20)}$, 
$\mathrm{Mg}-\mathrm{Pd}^{21-23)}, \mathrm{Mg}-\mathrm{Al}^{24)}, \mathrm{Mg}-\mathrm{Ti}^{2}-\mathrm{Ni}^{25)}$ などの超積層体の水素化 特性について集中的に研究されてきた。

例えば，通常の溶融法で作製された $\mathrm{Mg}_{2} \mathrm{Cu}$ 合金では, $573 \mathrm{~K}, 3.3 \mathrm{MPa}$ の水素䨌囲気下での初期活性化後, 水素吸 蔵・放出に $557 \mathrm{~K}$ 必要である ${ }^{26)}$. 一方, $\mathrm{Mg} / \mathrm{Cu}$ 超積層体は同 条件での初期活性化後, $473 \mathrm{~K}$ で可逆的に水素吸蔵・放出を 示す。我々の以前の研究から ${ }^{20)}, 573 \mathrm{~K}$ での $\mathrm{Mg} / \mathrm{Cu}$ 超積層体 の初期活性化の後, 大量のポアが生成することにより表面積 が増大し, 水素の侵入経路が増え水素吸蔵・放出に必要な拡 散距離が短くなるので, 水素・吸蔵速度が改善され, その結 果, 平衡状態での水素吸蔵・放出温度が $473 \mathrm{~K}$ に低下するこ とが知られている.

初期活性化時には, $\mathrm{Mg}$ の酸化を防ぐために, 水素を室温 で導入する. $\mathrm{Mg} / \mathrm{Cu}$ 超積層体の初期活性化 $(573 \mathrm{~K}, 3.3 \mathrm{MPa}$ の水素雲囲気での水素吸蔵と $573 \mathrm{~K}$, 真空下での水素放出)の 加熱過程において，水素吸蔵は約 $453 \mathrm{~K}$ で始まる。 ARB で作 製された $\mathrm{Mg} / \mathrm{Cu}$ 超積層体は Fig. 1 (a)に見られるように厚さ 数百 $\mathrm{nm}$ の $\mathrm{Mg}$ 層と $\mathrm{Cu}$ 層からなるので, 初期活性化の加熱過 程中の微細組織形成の初期ステージにおいて, $\mathrm{Mg}$ の水素化, $\mathrm{Mg}$ と $\mathrm{Cu}$ の合金化, それに続く $\mathrm{Mg}_{2} \mathrm{Cu}$ の水素化が競合的に 起こる27-29). このような競合的な多経路反応の結果として, 複雑な微細構造が形成される. Fig. 1(b)に見られるように, $\mathrm{ARB}$ 中にすでに $\mathrm{Mg}_{2} \mathrm{Cu}$ が $\mathrm{Mg}$ 層と $\mathrm{Cu}$ 層の界面に形成される ことに注目すべきである。

不可解なことであるが, $\mathrm{Mg} / \mathrm{Cu}$ 超積層体の初期水素化特 性は不安定であり, 同じ条件で作製されていても, 初期水素 化後の微細組織は多様である。それは, $\mathrm{Mg} / \mathrm{Cu}$ 超積層体が不 揃いで均一性に欠けた品質であるためと考えられる。

Fig. 1(c), Fig. 1(d), Fig. 1(e)は, 初期水素化後の $\mathrm{Mg} / \mathrm{Cu}$ 超積層体の典型的な 3 種類の微細構造の走査型電子顕微鏡 $(\mathrm{SEM})$ による射電子像である。これらは, 水素雰囲気
3.3 MPa， $573 \mathrm{~K} ， 86.4 \mathrm{ks}(24 \mathrm{~h})$ の条件下で Sieverts 型の装置を 使用して水素化されている。.Fig. 1(c) は，20 以上の ARB サ イクルを行った微細な as-rolled 構造を持った $\mathrm{Mg} / \mathrm{Cu}$ 超積層 体に通常見られる $\mathrm{MgCu}_{2}$ ネットワーク構造である. Fig. 1 (d) は, 10 回 ARB サイクルを行った中程度に微細な as-rolled 構造を持った $\mathrm{Mg} / \mathrm{Cu}$ 超積層体にしばしば見られる $\mathrm{MgCu}_{2}$ 鞘 構造である。Fig. 1(e)は，5回 ARB サイクルを行った粗い as-rolled 構造を持った $\mathrm{Mg} / \mathrm{Cu}$ 超積層体で主に見られる $\mathrm{MgCu}_{2}$ 層構造である。

Fig. 2 は 3 種類の示差走査熱量測定 (DSC)の第一サイクル と第二サイクルのプロファイルを示している．室温で $3.1 \mathrm{MPa}$ の水素が導入され, 加熱/冷却速度は $5 \mathrm{~K} / \mathrm{min}$ であった。水 素吸蔵・放出の平衡温度から判断して ${ }^{29)}$, 約 $720 \mathrm{~K}$ の吸熱・ 発熱ピークのペアは, $\mathrm{Mg}$ の水素吸蔵・放出のピークペアに 対応し, 約 $650 \mathrm{~K}$ のピークペアは, $\mathrm{Mg}_{2} \mathrm{Cu}$ の水素吸蔵・放出 のピークペアに対応する.

これらのプロファイルの特徵を以下に要約する.

Fig. 2(a)：第一サイクルの加熱過程において, $520 \mathrm{~K}$ 付近 に非常になだらかな発熱ピーク， $680 \mathrm{~K}$ 付近に $\mathrm{Mg}_{2} \mathrm{Cu}$ の水素 放出ピーク, $730 \mathrm{~K}$ 付近に $\mathrm{Mg}$ の水素放出ピークがある. 第 二サイクルの $\mathrm{Mg}_{2} \mathrm{Cu}$ の水素放出ピークは第一サイクルの水 素放出ピークより高く, 第二サイクルの $\mathrm{Mg}$ の水素放出ピー クは第一サイクルの水素放出ピークより低い。また，第一サ イクルの冷却過程において, $710 \mathrm{~K}$ 付近に $\mathrm{Mg}$ の水素吸蔵 ピークが, $630 \mathrm{~K}$ 付近に $\mathrm{Mg}_{2} \mathrm{Cu}$ の水素吸蔵ピークが見られ る。第一サイクルの冷却過程における $\mathrm{Mg}$ の水素吸蔵ピーク は小さく，第二サイクルにおいては，かろうじて見える程度 である．第二サイクルの $\mathrm{Mg}_{2} \mathrm{Cu}$ の水素吸蔵ピークは第一サ イクルより高い.

Fig. 2(b)：第一サイクルの加熱過程において, $650 \mathrm{~K}$ 付近 に非常になだらかな発熱ピークがある。また， $\mathrm{Mg}_{2} \mathrm{Cu}$ の水素

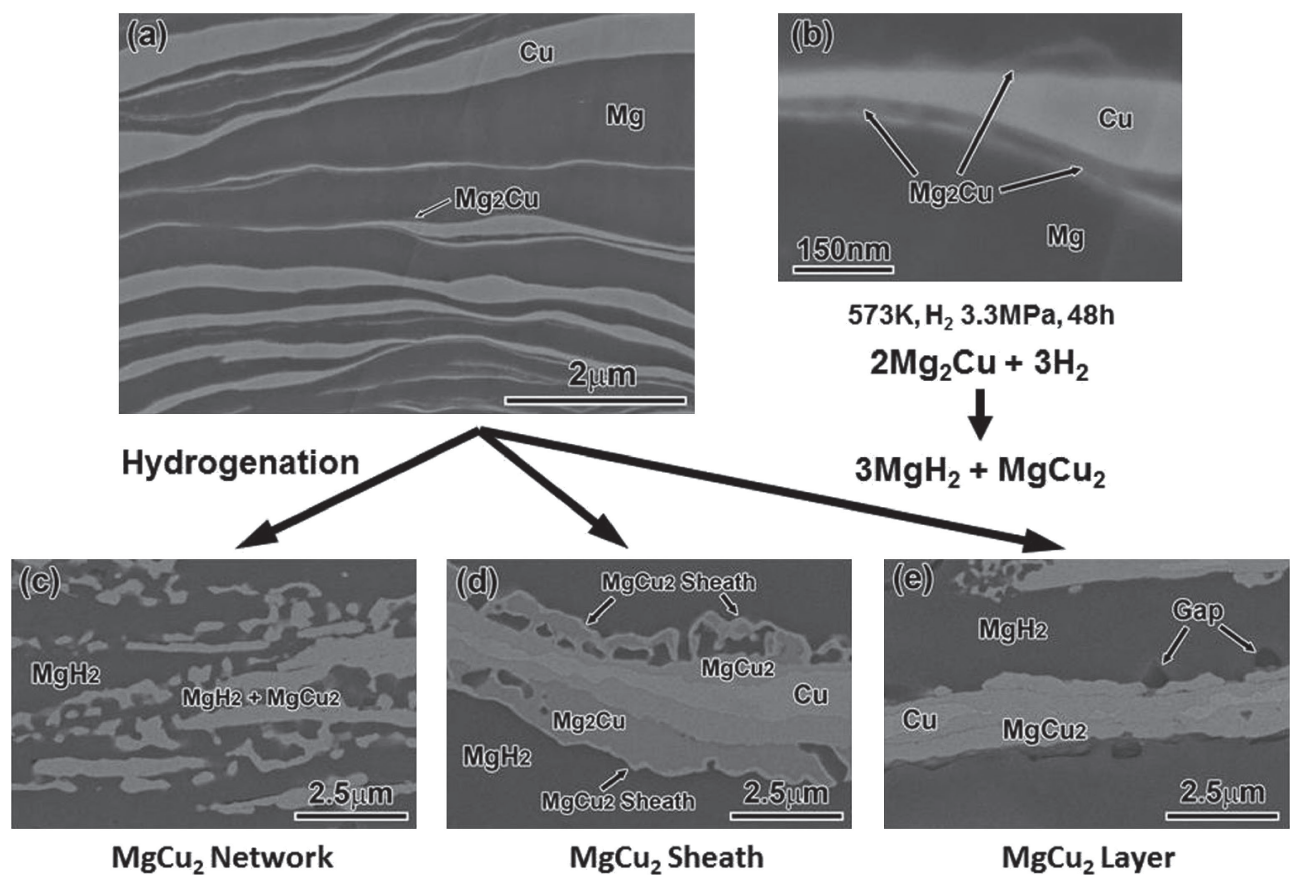

Fig. 1 Backscattered electron images by SEM of as-rolled and typical three types of microstructures in $\mathrm{Mg} / \mathrm{Cu}$ SLCs after initial hydrogenation: (a), (b) as-rolled, (c) $\mathrm{MgCu}_{2}$ network type, (d) $\mathrm{MgCu}_{2}$ sheath type and (e) $\mathrm{MgCu}_{2}$ layer type. 


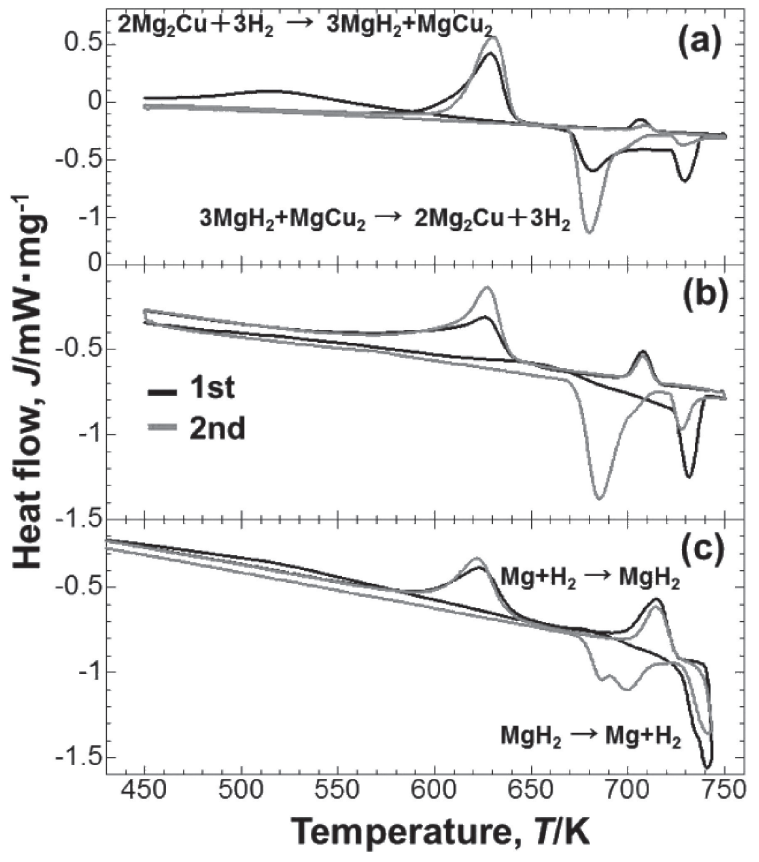

Fig. 2 Three types of DSC profiles of $\mathrm{Mg} / \mathrm{Cu}$ SLC in hydrogen atmosphere.

放出ピークはかすかに見られ, $730 \mathrm{~K}$ 付近の $\mathrm{Mg}$ の水素放出 ピークはFig. 2(a)のものより高い. 第二サイクルにおける $\mathrm{Mg}_{2} \mathrm{Cu}$ の水素放出ピークは明確で高く, 第二サイクルにおけ る $\mathrm{Mg}$ の水素放出ピークは第一サイクルより低い. 第一サイ クルの冷却過程において, $710 \mathrm{~K}$ 付近に $\mathrm{Mg}$ の水素吸蔵ピー クが見られ，それは，Fig. 2(a)よりも高い。また， $630 \mathrm{~K}$ 付 近に $\mathrm{Mg}_{2} \mathrm{Cu}$ の水素吸蔵ピークが見られ, それは低温側に長 いテールを引いている。第一サイクルの冷却過程における $\mathrm{Mg}$ の水素吸蔵ピークは, 第二サイクルのものとほとんど同 じ高さである。第二サイクルの $\mathrm{Mg}_{2} \mathrm{Cu}$ の水素吸蔵ピークは 第一サイクルのものより高く，長いテールも示す.

Fig. 2(c)：第一サイクルの加熱過程において, $520 \mathrm{~K}$ 付近 に極めてなだらかな発熱ピークがある。.また, $\mathrm{Mg}_{2} \mathrm{Cu}$ の水素 放出ピークはかすかに見られ, $730 \mathrm{~K}$ 付近の $\mathrm{Mg}$ の水素放出 ピークは, Fig. 2(a), Fig. 2(b), Fig. 2(c)の中で一番高い. 第二サイクルの $\mathrm{Mg}_{2} \mathrm{Cu}$ の水素放出ピークはダブルピークに なっており，第二サイクルの $\mathrm{Mg}$ の水素放出ピークは第一サ イクルより低い. $710 \mathrm{~K}$ 付近に $\mathrm{Mg}$ の水素吸蔵ピークが見ら れ, それは, Fig. 2(a), Fig. 2(b), Fig. 2(c)の中で一番高い. そして, 第一サイクルの冷却過程において, $630 \mathrm{~K}$ 付近の $\mathrm{Mg}_{2} \mathrm{Cu}$ の水素吸蔵ピークは Fig. 2(b)のような低温に向かっ てのテールを示さない。第一サイクルの冷却過程における $\mathrm{Mg}$ の水素吸蔵ピークは, 第二サイクルとほとんど同じ高さ である. $\mathrm{Mg}_{2} \mathrm{Cu}$ の水素吸蔵ピークも $\mathrm{Mg}$ と同じ傾向を示す.

上記の特徵は, DSC 測定 20 回目でさえも現れる ${ }^{19)}$. この ことは, $\mathrm{Mg} / \mathrm{Cu}$ 超積層体の初期構造は水素吸蔵・放出特性に おいて重要な役割を果たすことを示唆している.

初期水素化後の $\mathrm{Mg} / \mathrm{Cu}$ 超積層体の微細構造と水素吸蔵・ 放出特性の多様性は, $\mathrm{Mg} / \mathrm{Cu}$ 超積層体の不揃いで均一性に欠 けた品質に原因があると考えられる。しかしながら，それら の詳細はまだ十分には理解されていない，それゆえ，均一で
優れた物性を具現化するために，なぜこのような微細構造と 物性の違いが現れるのか明らかにすることは, 重要である. この論文では, $\mathrm{Mg} / \mathrm{Cu}$ 超積層体における初期水素化過程にお ける競合反応を通じた微細組織形成機構および微細組織と水 素吸蔵・放出特性の関係を研究した。ここでは, 微細組織の 観点から, 初期水素化過程における競合反応の順序と温度領 域と ARB の物理的意味を明らかにした。また，今までの論 文では19,20,27-29)，微細組織と水素吸蔵・放出特性の関係につ いて述べただけであったが, $\mathrm{Mg} / \mathrm{Cu}$ 超積層体の作製過程にお いて再考すべき点も指摘した.

\section{2. 実 験 方 法}

$\mathrm{Mg} / \mathrm{Cu}$ 超積層体を得るために $\mathrm{ARB}$ が用いられた。出発材 料として市販の純 $\mathrm{Mg}$ (竹内金属䇴粉工業(侏), 純度 $99.9 \%$, 厚 さ $250 \mu \mathrm{m}$ ) と無酸素 $\mathrm{Cu}$ (福田金属箔粉工業(侏)，純度 $99.98 \%$, 厚さ $10 \mu \mathrm{m})$ が用いられた。 $\mathrm{Mg}$ 䇴は，酸化膜を取り除くため に\#600のサンドペーパーで磨かれた後に厚さ $40 \mu \mathrm{m}$ に冷間 圧延された。これらの厚さ $40 \mu \mathrm{m}$ の $\mathrm{Mg}$ 箔と厚さ $10 \mu \mathrm{m}$ の $\mathrm{Cu}$ 䈃は, $20 \mathrm{~mm} \times 40 \mathrm{~mm}$ にカットされた。 その後, それらは内 部応力や歪みを除去するために, $0.1 \mathrm{MPa}$ の $\mathrm{Ar}$ 雲囲気中で $3.6 \mathrm{ks}, \mathrm{Mg}$ は $673 \mathrm{~K}$ で, $\mathrm{Cu}$ は $873 \mathrm{~K}$ でそれぞれ焼鈍された. 両方の䇴の表面は，Mg は希塩酸， $\mathrm{Cu}$ は希硝酸でそれぞれ洗 浄された. $\mathrm{Mg}_{2} \mathrm{Cu}$ の化学量論組成になるように, 厚さ $40 \mu \mathrm{m}$ の $\mathrm{Mg}$ 䈃と厚さ $10 \mu \mathrm{m}$ の $\mathrm{Cu}$ 䇴のペア 20 組が 1 つにまとめら れた. $\mathrm{ARB}$ 中の $\mathrm{Mg}$ と $\mathrm{Cu}$ の滑りを防ぎ，接着性を高めるた めに，この積層体は厚さ $1 \mathrm{~mm}$ の $\mathrm{Cu}$ 板で包まれ， $735 \mathrm{MPa}$, $300 \mathrm{~s}$ の条件下でプレスされた。 その積層体は空気中室温で, 通常の圧延接合プロセスで冷間圧延された。そして，元の長 さの 2 倍に圧延された材料は半分に切断された．その切断さ れた薄膜の 1 つはもう 1 つの上に重ねられ， $\mathrm{Cu}$ 板で包まれ， 再び圧延された。この手順の繰り返しにより $\mathrm{Mg} / \mathrm{Cu}$ 超積層 体が作製された，実際のところ，ARB 圧延は変形法であるた けでなく，接合プロセスでもある。また，このプロセスによ り, 幾何学的な変化なく極めて高い塑性歪みを導入すること ができる30).

表面領域の半分は, ARB プロセスの次のサイクルでは, 中 央になることを知っておくことは重要である，これは，大き なせん断歪みを持つ表面領域が䇴の厚さ全体にわたって複雑 に分布する結果になる。異なる初期(圧延まま)構造を得るた めに，上記手順の回数を変化させて，4種類の試料が作製さ れた。それらは, ARB サイクル 5 回, 10 回, 20 回, 30 回で ある。

ARB のサイクル数に依存した水素吸蔵・放出特性を理解す るために, $\mathrm{Mg} / \mathrm{Cu}$ 超積層体は $3.3 \mathrm{MPa}$ の水素雲囲気, $573 \mathrm{~K}$ で $86.4 \mathrm{ks}$ の条件で水素化された

$\mathrm{Mg}-\mathrm{Cu}$ 拡散対の実験から ${ }^{31,32)}$, 高温状態における $\mathrm{Mg} / \mathrm{Cu}$ 超積層体中では， $\mathrm{Mg}$ 層中を $\mathrm{Cu}$ が拡散し $\mathrm{Mg}$ 層と $\mathrm{Cu}$ 層の界 面において, $\mathrm{Mg}$ 側に $\mathrm{Mg}_{2} \mathrm{Cu}$ が, $\mathrm{Cu}$ 側に $\mathrm{MgCu}_{2}$ が形成され ることが知られている ${ }^{19,29)}$. ARB サイクル数の異なる $\mathrm{Mg} /$ $\mathrm{Cu}$ 超積層体における $\mathrm{Mg}_{2} \mathrm{Cu}$ の成長係数を知るために, $\mathrm{Mg} /$ $\mathrm{Cu}$ 超積層体の拡散焼鈍が行われた. $\mathrm{MgCu}_{2}$ は $473 \mathrm{~K}$ 以下で 
は形成されないことが指摘されており ${ }^{33,34)}$, 我々の以前の研 究から $\mathrm{Mg} / \mathrm{Cu}$ 超積層体は約 $453 \mathrm{~K}$ から水素吸蔵を開始する ことが知られているので, $453 \mathrm{~K}$ 以下の温度で拡散焼鈍は行 われた。拡散焼鈍中の $\mathrm{Mg}_{2} \mathrm{Cu}$ 層の成長距離は SEM 観察と $\mathrm{X}$ 線回折 (XRD) の積分強度比解析の組み合わせで評価された. $\mathrm{Mg} / \mathrm{Cu}$ 超積層体における $\mathrm{Mg}_{2} \mathrm{Cu}$ の成長係数の測定方法の詳 細は, 文献 35)に報告されている。 また, ARB サイクル数の 異なる $\mathrm{Mg} / \mathrm{Cu}$ 超積層体の成長係数の実験結果の詳細は, 別 のところで報告する予定である.

加熱中 (合金化過程)に生成する相の形成順序を見積もるた め, $\mathrm{Mg} / \mathrm{Cu}$ 超積層体の小片が, $3.1 \mathrm{MPa}$ の $\mathrm{Ar}$ 雲囲気下で加 熱速度 $10 \mathrm{~K} / \mathrm{min}, 50 \mathrm{~K}$ 間隔で 423-773 K までの間まで加熱さ れ，DSC 装置のヒーターを切ることにより冷却された．構成 層は, 粉末 XRD 法とエネルギー分散型 X 線分光法 (EDS)に より確かめられた.

$\mathrm{ARB}$ サイクル 20 回の $\mathrm{Mg} / \mathrm{Cu}$ 超積層体の初期水素化中の 競合反応の温度域を知るために, $3.1 \mathrm{MPa}$ の水素および $\mathrm{Ar}$ 雲 囲気下で加熱 ·冷却温度速度 $10 \mathrm{~K} / \mathrm{min}, 373-753 \mathrm{~K}$ の温度域 で $\mathrm{Mg} / \mathrm{Cu}$ 超積層体の小片の DSC 測定が行われた. Ar 雲囲 気下での DSC 測定は, 水素化前の加熱中 (合金化過程)の反 応を見積もるために行われ, 水素化過程の反応を知るために 水素雲囲気下の DSC 測定と Ar 雲囲気下での DSC 測定の差 分が評価された，DSCプロファイルは，バックグラウンドを 引いた後, 擬フォークト関数によりピークフィッティングさ れた。

この研究では, DSC プロファイルは上述した競合反応によ る多くのピークを含んでいると考えられている。これらの競 合反応におけるそれぞれの構成反応の温度域に関する情報を 得るために, ピーク分離が試みられた。 それぞれの反応につ いて, 複雑な理論的アプローチに基づいてプロファイルと実
験データをフィッティングするためには（活性化エネルギー， 成長係数, 変化効率等々)多くのパラメーターが必要である. しかしながら，これらのパラメーターについては不十分な デー夕しかない。 今回, 我々は, 大まかな温度域を知るため に, 化学反応に対する理論的なアプローチから離れ, ガウシ アンとローレンチアンからなる簡単な擬フォークト関数を適 用してプロファイル・フィッテイングを行った.

$\mathrm{Mg} / \mathrm{Cu}$ 超積層体の微細組織は, SEM と走査透過型電子顕 微鏡 $(\mathrm{STEM})$ を用いて観察された.SEM とSTEM 試料は通常 の機械研磨とイオン研磨により作製された.

競合反応を通じた初期水素化過程における $\mathrm{Mg} / \mathrm{Cu}$ 超積層 体の微細組織形成機構は, $\mathrm{Mg} / \mathrm{Cu}$ 超積層体の成長係数, XRD プロファイル, DSCプロファイル，そして微細組織を 評価することから推測された.

\section{3. 結果と考察}

$3.3 \mathrm{MPa}$ の水素䨌囲気中, $573 \mathrm{~K}, 86.4 \mathrm{ks}(24 \mathrm{~h})$ の条件下に おいての $\mathrm{ARB}$ サイクル数の異なる圧延ままの $\mathrm{Mg} / \mathrm{Cu}$ 超積層 体の初期水素化特性は, 次のようになる. ARB サイクル数 5 回, 10 回の $\mathrm{Mg} / \mathrm{Cu}$ 超積層体は水素をゆっくり吸蔵する。一 方, $\mathrm{ARB}$ サイクル 20 回, 30 回の $\mathrm{Mg} / \mathrm{Cu}$ 超積層体は, 速く 水素を吸蔵する ${ }^{36)}$. これらの試料の SEM 観察から, 水素吸 蔵後の $\mathrm{Mg}_{2} \mathrm{Cu}$ のネットワークの総合面積は, 30 回 $>20$ 回> 10 回 $>5$ 回の順になる。このことは, ARB サイクル数 20 回 以上と 10 回以下では, 組織形成プロセスに何らかの違いが あることを示唆している.

Fig. 3 は, ARB サイクル数の異なる $\mathrm{Mg} / \mathrm{Cu}$ 超積層体の DSC プロファイルを示している．室温にて $3.1 \mathrm{MPa}$ の水素が 導入され, 室温から $753 \mathrm{~K}$ までの加熱速度は $20 \mathrm{~K} / \mathrm{min}$,
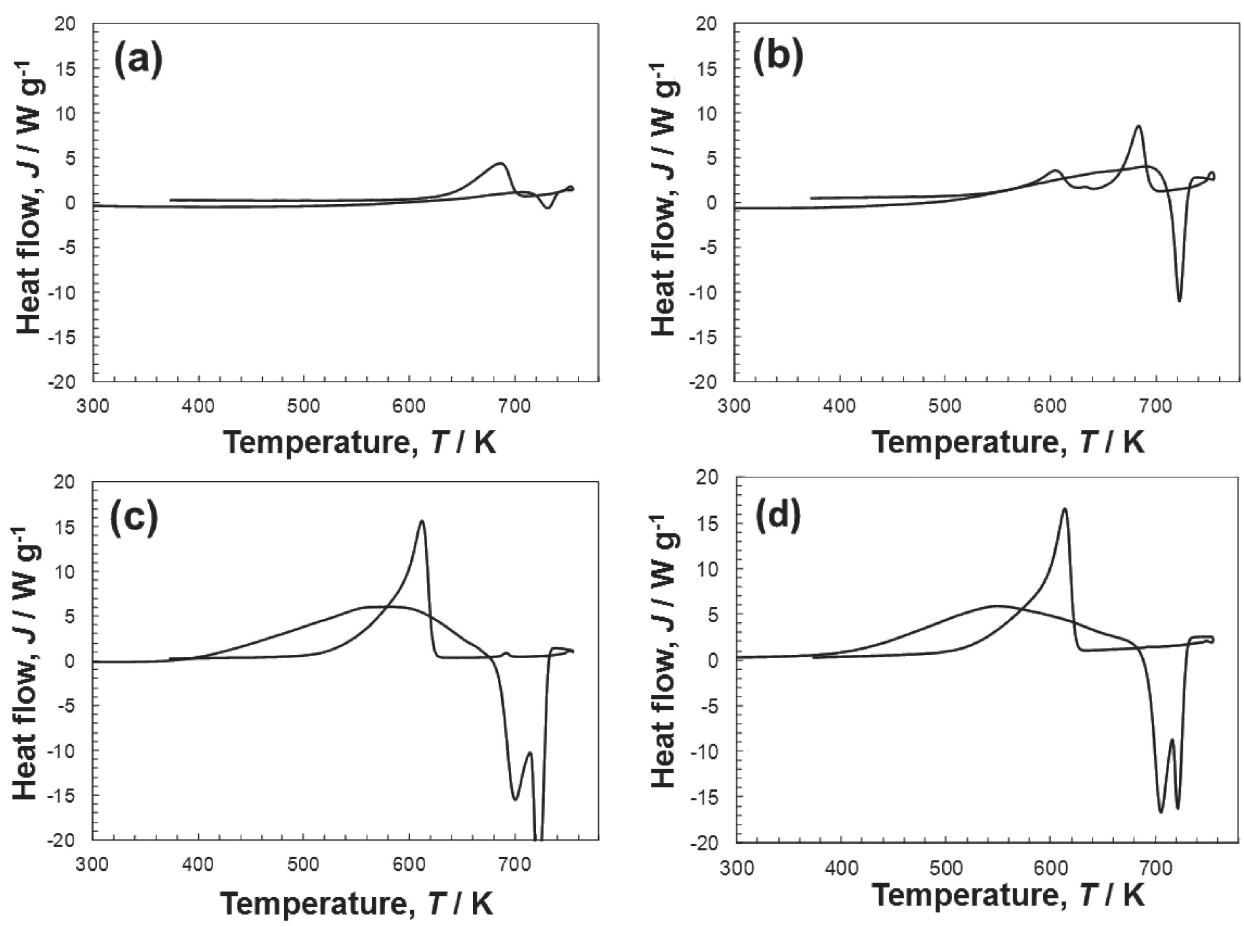

Fig. 3 DSC profiles of Mg/Cu SLCs with different ARB cycles: (a) 5 cycles of ARB, (b) 10 cycles, (c) 20 cycles and (d) 30 cycles. 
$753 \mathrm{~K}$ から $373 \mathrm{~K}$ までの冷却速度は $10 \mathrm{~K} / \mathrm{min}$ であった。加熱 過程において, ARB サイクル数 5 回と 10 回の試料では, $\mathrm{Mg}$ の水素放出ピークだけが Fig. 3(a)，Fig. 3(b)に見られる。一 方, 加熱過程において, ARB サイクル数 20 回と 30 回の試料 では, $\mathrm{Mg}_{2} \mathrm{Cu}$ の水素放出ピークも Fig. 3(c), Fig. 3(d)に見 られる。このことは, 加熱過程において, ARB サイクル 5 回 と 10 回の $\mathrm{Mg} / \mathrm{Cu}$ 超積層体では, 十分な量の $\mathrm{Mg}_{2} \mathrm{Cu}$ が生成 されなかったことを示唆している. $\mathrm{Mg}_{2} \mathrm{Cu}$ の水素吸蔵ピーク は, Fig. 3(a)では見られず，Fig. 3(b)では小さく，Fig. 3 (c), Fig. 3(d)では, 大きく見られることから, ARB サイク ル 10 回と 20 回の間で, 水素吸蔵メカニズムに何らかの違い があるように見える。これらの結果から， ARB サイクル 20 回と 30 回の $\mathrm{Mg} / \mathrm{Cu}$ 超積層体では, $\mathrm{Mg}_{2} \mathrm{Cu}$ の水素化が支配的 であり, $\mathrm{ARB}$ サイクル 5 回と 10 回の $\mathrm{Mg} / \mathrm{Cu}$ 超積層体では, $\mathrm{Mg}$ の水素化が支配的であると言うことができる.

$\mathrm{Mg} / \mathrm{Cu}$ 超積層体中の $\mathrm{Mg}_{2} \mathrm{Cu}$ の成長率係数は, $\mathrm{ARB}$ サイク ル数の増加に伴って増加すると考えられるので, 異なる $\mathrm{ARB}$ サイクルの数の $\mathrm{Mg} / \mathrm{Cu}$ 超積層体中の $\mathrm{Mg}_{2} \mathrm{Cu}$ の成長率係数を 調べた ${ }^{35)}$. $\mathrm{Mg}$ 䈃と $\mathrm{Cu}$ 䇴の接触が不十分であるため $\mathrm{Mg}_{2} \mathrm{Cu}$ が十分に成長しなかったので, ARB サイクル数 5 回の $\mathrm{Mg}$ / $\mathrm{Cu}$ 超積層体の成長率係数は測定できなかったが, ARB サイ クル数 10 回, 20 回, 30 回の $\mathrm{Mg} / \mathrm{Cu}$ 超積層体の拡散焼鈍の 結果から, $\mathrm{Mg}_{2} \mathrm{Cu}$ 層の成長率係数 $k$ は以下のようにアレニウ ス方程式で表現できることがわかった ${ }^{31,32,35) .}$

$$
k=k_{0} \exp (-Q / R T)
$$

ここで, $k_{0}$ は頻度因子, $Q$ は $\mathrm{Mg}_{2} \mathrm{Cu}$ 層の層成長過程にお ける活性化エネルギー, $R$ はガス定数, $T$ は拡散焼鈍温度で ある. $\mathrm{Mg}$ と $\mathrm{Cu}$ の平均厚さと, $\mathrm{ARB}$ サイクル 10 回, 20 回, 30 回の $Q$ と $k_{0}$ および, それらから計算により求まる各温度 での $k$ は Table 1 にまとめられている.

$\mathrm{Mg} / \mathrm{Cu}$ 超積層体中の $\mathrm{Mg}_{2} \mathrm{Cu}$ 層の層成長過程に対する活性 化エネルギーは, $\mathrm{Mg}-\mathrm{Cu}$ 拡散対のものよりはるかに低いこと がわかる31,32). 結果として, $\mathrm{Mg} / \mathrm{Cu}$ 超積層体中の $\mathrm{Mg}_{2} \mathrm{Cu}$ の 成長率係数は, $\mathrm{Mg}-\mathrm{Cu}$ 拡散対のものより, $453 \mathrm{~K}$ 以下ではお およそ $10^{2}-10^{4}$ 倍大きくなる。このことは, $\mathrm{Mg}_{2} \mathrm{Cu}$ が, $\mathrm{Mg} /$ $\mathrm{Cu}$ 超積層体中, 低温でも十分な速度で成長できることを示 唆している. ARBにより成長率係数が増大したと言える。し かしながら, 予想に反して, ARB サイクルの異なる $\mathrm{Mg} / \mathrm{Cu}$ 超積層体間では，大きな違いはなかった。高圧ねじり法 (high-pressure torsion, HPT) や, 等チャネル角度プレス法 (equal-channel angular pressing, ECAP)のような強塑性変形 (severe plastic deformation, SPD) は, 原子空孔, 転位, 結晶
粒界のような格子久陥の密度を上げるので，原子拡散を高 め, 固相反応を推進すると報告されている35,37-41). よって, ARB 過程においても, 高密度の原子空孔や転位の導入や結晶 粒微細化を考えることは合理的である.

$\mathrm{ARB}$ サイクル 5 回, 10 回の圧延まま $\mathrm{Mg} / \mathrm{Cu}$ 超積層体にお ける高密度の転位の導入と結晶粒微細化は, 参考文献 36)に おいて，STEM 観察によって確かめられている。ARB サイク ル 5 回の場合, $\mathrm{Mg}$ の平均粒径は $590 \mathrm{~nm}$ であり, $\mathrm{ARB}$ サイ クル 20 回の場合の $180 \mathrm{~nm}$ より大きかった。(平均粒径は, 平均層厚さではないことに注意. ) しかしながら,これは組織 の不均一性のためである. ARB サイクル 5 回の $\mathrm{Mg} / \mathrm{Cu}$ 超積 層体のほとんどの結晶粒の平均結晶粒径は, ARB サイクル 20 回のものとほぼ同じである. ARB サイクル 5 回の $\mathrm{Mg} / \mathrm{Cu}$ 超積層体中の大きな結晶粒が平均粒径を大きくしているだけ である．両方の試料で, $\mathrm{Mg}$ と $\mathrm{Cu}$ の転位密度は高かった，参 考文献 36）の Fig. 5(b)（ARB サイクル 5 回）と Fig. 5(d) (ARB サイクル 20 回)に見られるように, $\mathrm{Cu}$ についても同じ ことが言える。これが, $\mathrm{ARB}$ サイクル数 10 回, 20 回, 30 回の $\mathrm{Mg} / \mathrm{Cu}$ 超積層体の成長率定数がほとんど同じである理 由である。

Fig. 4 は, 異なる ARB サイクルの $\mathrm{Mg} / \mathrm{Cu}$ 超積層体におけ る $\mathrm{Mg}_{2} \mathrm{Cu}$ 体積率の時間と温度依存性のシミュレーションで ある. Table 1 の $\mathrm{Mg}$ と $\mathrm{Cu}$ の厚さ， $k_{0}, Q$ が用いられた. $\mathrm{ARB}$ サイクル 20 回の Fig. 4(b) と ARB サイクル 30 回の Fig. 4(c)の特徵はほとんど同じであるが, ARB サイクル 10 回の Fig. 4(a) はこれらとは異なっている. 同じ時間, 同じ温 度の $\mathrm{Mg}_{2} \mathrm{Cu}$ 体積率は $\mathrm{ARB}$ サイクル数の増加に伴って大きく なると言える. なぜなら, ARB サイクル数が増加すれば, $\mathrm{Mg}_{2} \mathrm{Cu}$ が成長する場所である $\mathrm{Mg}$ と $\mathrm{Cu}$ の界面の数が増え， $\mathrm{Cu}$ が拡散する $\mathrm{Mg}$ 層の厚さが減少するからである. Fig. 5 は, $\mathrm{ARB}$ サイクル数に対する $\mathrm{Mg} / \mathrm{Cu}$ 超積層体における $\mathrm{Mg}$ 層の厚さを示している. $\mathrm{ARB}$ サイクル数 5 回以上で, $\mathrm{Mg}$ 層 の厚さが劇的に減少していること, ARB サイクル数 20 回と 30 回では $\mathrm{Mg}$ 層の厚さがほとんど同じであることががはっき りとわかる. ARB サイクル数 10 回, 20 回, 30 回の $\mathrm{Mg} / \mathrm{Cu}$ 超積層体では, 成長率定数がほとんど同じであるので, $\mathrm{Mg}_{2} \mathrm{Cu}$ の同温度・同時間での成長長さはそれらの間でほぼ同 じであるはずである。したがって，（Mg 層中を $\mathrm{Cu}$ が拡散す るので ${ }^{31,32)}$ もし $\mathrm{Mg}$ 層が厚ければ，ある温度のある時間内で は, $\mathrm{Mg}$ は完全には $\mathrm{Mg}_{2} \mathrm{Cu}$ に変化することができない場合が 生じる.これが, ARB サイクル数 10 回, 20 回, 30 回の $\mathrm{Mg} / \mathrm{Cu}$ 超積層体の成長率定数がほとんど同じであるにもかか

Table 1 List of the thickness of $\mathrm{Mg}$ and $\mathrm{Cu}$, the activation energy $Q$, pre-exponential factor $k_{0}$ and growth rate constants $k$ at several temperatures for the layer growth process of $\mathrm{Mg}_{2} \mathrm{Cu}$ layers in $\mathrm{Mg} / \mathrm{Cu}$ SLCs an $\mathrm{Mg}-\mathrm{Cu}$ diffusion couples.

\begin{tabular}{cccccccc}
\hline & \multicolumn{2}{c}{ Thickness } & $Q\left(\mathrm{kJmol}^{-1}\right)$ & $k_{0}\left(\mathrm{~m}^{2} \mathrm{~s}^{-1}\right)$ & \multicolumn{2}{c}{$k\left(\mathrm{~m}^{2} \mathrm{~s}^{-1}\right)$} \\
\cline { 2 - 8 } $\begin{array}{c}\text { Samples } \\
\text { Mg-Cu }\end{array}$ & $\mathrm{Mg}(\mathrm{nm})$ & $\mathrm{Cu}(\mathrm{nm})$ & & & $373 \mathrm{~K}$ & $413 \mathrm{~K}$ & $453 \mathrm{~K}$ \\
diffusion couples $^{26)}$ & 4000 & 4000 & $156 \pm 10$ & $1.5 \times 10^{-3}$ & $2.0 \times 10^{-25}$ & $2.7 \times 10^{-23}$ & $1.5 \times 10^{-21}$ \\
10 ARB & 443 & 162 & $101 \pm 12$ & $9.3 \times 10^{-8}$ & $1.2 \times 10^{-21}$ & $1.7 \times 10^{-20}$ & $4.1 \times 10^{-19}$ \\
20 ARB & 173 & 65 & $103 \pm 12$ & $6.4 \times 10^{-7}$ & $2.2 \times 10^{-21}$ & $9.5 \times 10^{-20}$ & $7.7 \times 10^{-19}$ \\
30 ARB & 123 & 64 & $107 \pm 2$ & $8.7 \times 10^{-7}$ & $1.7 \times 10^{-21}$ & $4.6 \times 10^{-20}$ & $7.6 \times 10^{-19}$ \\
\hline
\end{tabular}


(a)

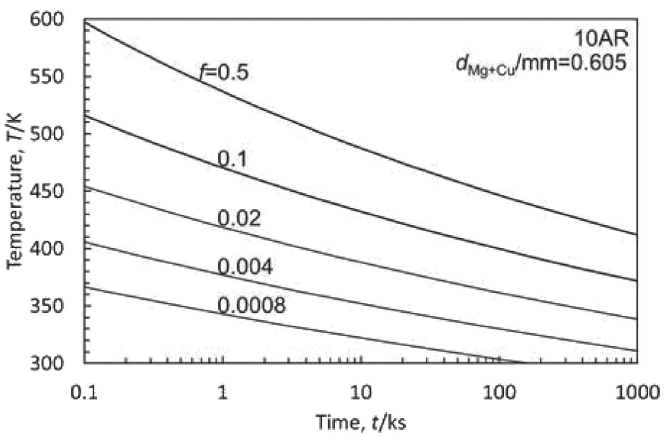

(b)

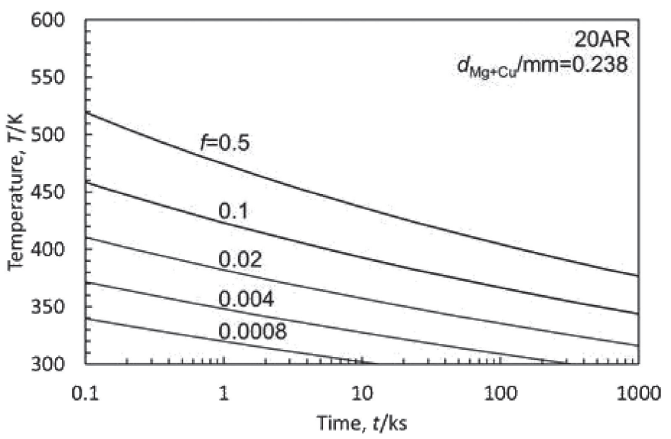

(c)

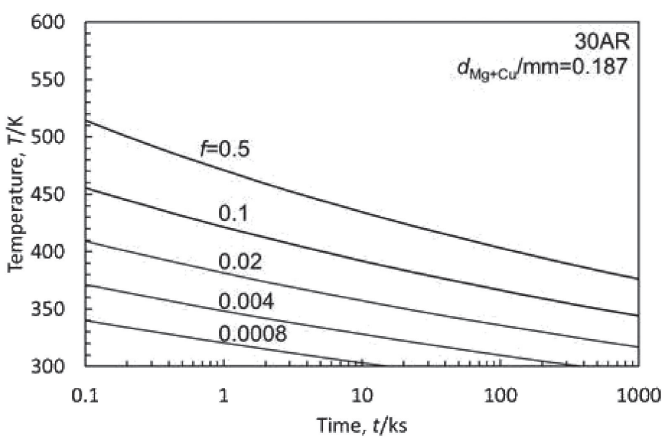

Fig. 4 Simulation of dependency on time and temperature of $\mathrm{Mg}_{2} \mathrm{Cu}$ volume ratio in $\mathrm{Mg} / \mathrm{Cu}$ SLCs with different ARB cycles: (a) 10 cycles of ARB, (b) 20 cycles and (c) 30 cycles.

わらず, $\mathrm{ARB}$ サイクル数 20 回と 30 回の $\mathrm{Mg} / \mathrm{Cu}$ 超積層体で は $\mathrm{Mg}_{2} \mathrm{Cu}$ の水素化が支配的であり, $\mathrm{ARB}$ サイクル数 5 回と 10 回の $\mathrm{Mg} / \mathrm{Cu}$ 超積層体では $\mathrm{Mg}$ の水素化が支配的である理 由である。

Fig. 6(a) は, $3.1 \mathrm{MPa} の \mathrm{Ar}$ 䨌囲気中で加熱速度 $10 \mathrm{~K} / \mathrm{min}$ で $753 \mathrm{~K}$ まで加熱された $\mathrm{Mg}_{2} \mathrm{Cu}$ 超積層体の DSC プロファイ ルである。すでに，バックグランドは引かれている. Fig. 6 (a)における放熱ピークは, 第 1 回目のサイクルの加熱過程 でのみ見られ，第 2 回目のサイクル以降は見られないことか ら, これらのピークは $\mathrm{Mg}$ と $\mathrm{Cu}$ の合金化過程と関係してい ると考えられる。擬フォークト関数を使ったピーク . フィッテイングにより，4つのピークに分解された. Fig. 6 (b) は, $3.1 \mathrm{MPa}$ の水素雲囲気中で加熱速度 $10 \mathrm{~K} / \mathrm{min}$ で $753 \mathrm{~K}$ まで加熱された $\mathrm{Mg} / \mathrm{Cu}$ 超積層体の DSC プロファイルから Fig. 6(a)を引いた DSC プロファイルである.これもまた, 擬フォークト関数を用いたピーク・フィッティングにより 2 つのピークに分けられた．SEM，STEM 観察，XRD， DSC 測 定から, DSC プロファイルのそれぞれのピークは, 下のよう に各反応に対応づけられた42).

Peak 1：Cuの回復および再結晶

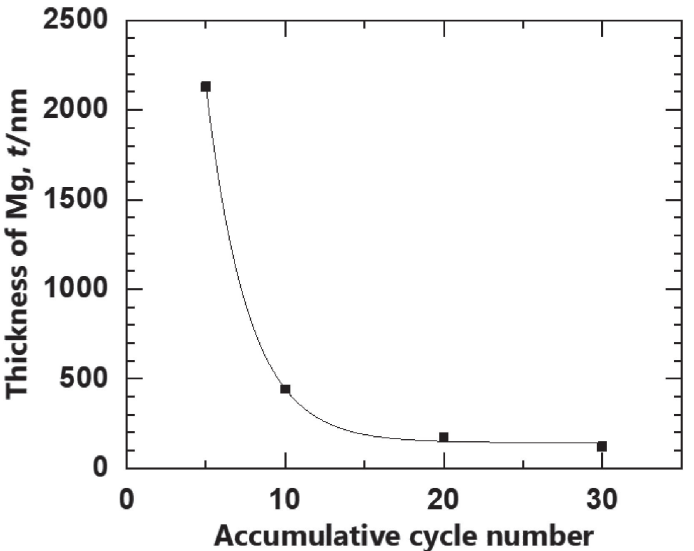

Fig. 5 Thickness of $\mathrm{Mg}$ in $\mathrm{Mg} / \mathrm{Cu}$ SLCs as a function of the number of ARB cycles.
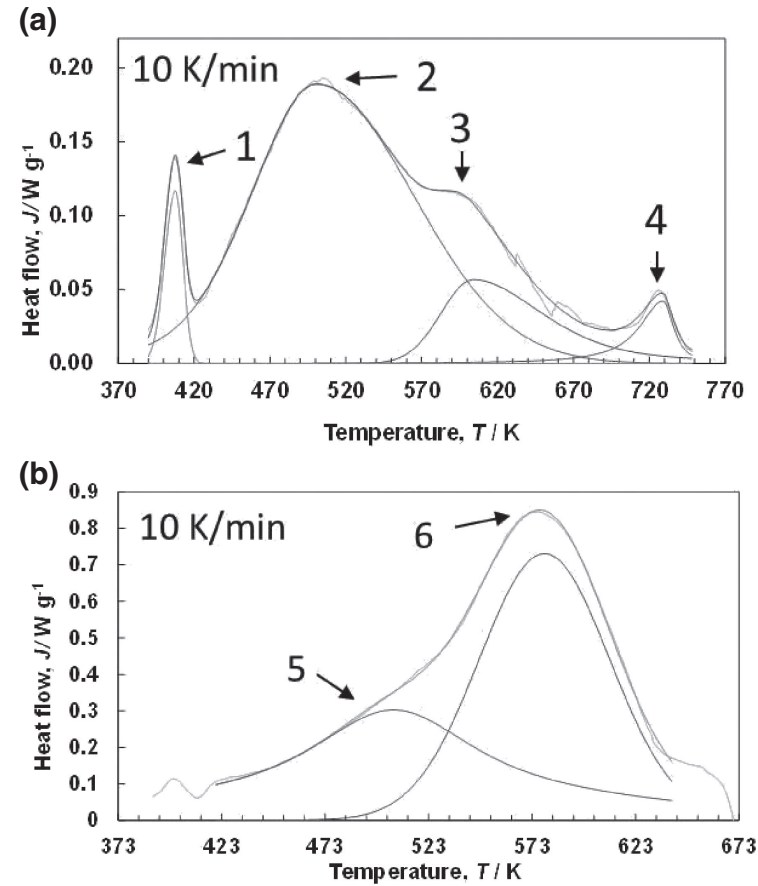

Fig. 6 DSC profile of $\mathrm{Mg} / \mathrm{Cu}$ SLCs: (a) heated up to $753 \mathrm{~K}$ at the heating rate of $10 \mathrm{~K} / \mathrm{min}$ in $\mathrm{Ar}$ atmosphere of $3.1 \mathrm{MPa}$, (b) subtraction of (a) from a DSC profile of $\mathrm{Mg} / \mathrm{Cu}$ SLCs heated up to $753 \mathrm{~K}$ at the heating rate of $10 \mathrm{~K} / \mathrm{min}$ in $\mathrm{H}_{2}$ atmosphere of $3.1 \mathrm{MPa}$.

Peak 2: $\mathrm{Mg}_{2} \mathrm{Cu}$ の生成, $2 \mathrm{Mg}+\mathrm{Cu} \rightarrow \mathrm{Mg}_{2} \mathrm{Cu}$ （2）

Peak $3: \mathrm{MgCu}_{2}$ の生成, $\mathrm{Mg}+2 \mathrm{Cu} \rightarrow \mathrm{MgCu}_{2}$ または $\mathrm{Mg}_{2} \mathrm{Cu}+$ $3 \mathrm{Cu} \rightarrow 2 \mathrm{MgCu}_{2} \quad$ (3)

Peak $4: \mathrm{Mg}_{2} \mathrm{Cu}$ の生成, $3 \mathrm{Mg}+\mathrm{MgCu}_{2} \rightarrow 2 \mathrm{Mg}_{2} \mathrm{Cu}$ (4)

Peak 5: $\mathrm{Mg}$ の水素化, $\mathrm{Mg}+\mathrm{H}_{2} \rightarrow \mathrm{MgH}_{2}$ （5）

Peak 6: $\mathrm{Mg}_{2} \mathrm{Cu}$ の水素化, $2 \mathrm{Mg}_{2} \mathrm{Cu}+3 \mathrm{H}_{2} \rightarrow 3 \mathrm{MgH}_{2}+\mathrm{Mg}-$ $\mathrm{Cu}_{2} \quad$ (6)

Fig. 7 は, 競合反応の温度範囲と反応強度を表した概略図 である. Fig. 2 を反映して脱水素化反応を含んでいる. 水平 な棒の厚さは, 反応強度を定性的に示している. Fig. 7 から, $\mathrm{Mg} / \mathrm{Cu}$ 超積層体の初期活性化の加熱過程における微細組織形 成の初期段階において, $\mathrm{Mg}_{2} \mathrm{Cu}$ の生成 $(\mathrm{Mg}$ と $\mathrm{Cu}$ の合金化) (2) とそれに続く $\mathrm{Mg}_{2} \mathrm{Cu}$ の水素化(6)と $\mathrm{Mg}$ の水素化 (5)が競 合していることが容易に理解できる。 $\mathrm{Mg}-\mathrm{Cu}$ 拡散対の実験か 
$ら^{31,32)}$ ，加熱過程においてコア-シェルのような構造が形成さ れると期待される19,29).

組織形成機構は, $\mathrm{Mg}$ と $\mathrm{Mg}_{2} \mathrm{Cu}$ の水素化の順序に応じて以 下のように 3 つの場合に分類することができる.

Case I : $\mathrm{Mg}$ の水素化(5)が $\mathrm{Mg}_{2} \mathrm{Cu}$ の水素化(6)の後に起こる. Case II : $\mathrm{Mg}$ の水素化(5)が, $\mathrm{Mg}_{2} \mathrm{Cu}$ の生成(2)の後, $\mathrm{Mg}_{2} \mathrm{Cu}$ の水素化(6)の前に起こる.

Case III : $\mathrm{Mg}$ の水素化 (5)が $\mathrm{Mg}_{2} \mathrm{Cu}$ の生成 (2)の前に起こる.
Fig. 8 は, $\mathrm{Mg} / \mathrm{Cu}$ 超積層体の初期水素化における競合反応 を通じた微細組織形成機構の概略モデルである。もし，コア 中に $\mathrm{Mg}$ と $\mathrm{Cu}$ が共存するようなコアーシェルのような構造 全体を考えると，多くの構造が存在し得る。しかしながら， $\mathrm{Mg}$ と $\mathrm{Cu}$ の界面における反応が重要であって, コアーシェル のような構造の内側は本質的ではない。 それゆえ, Fig. 1

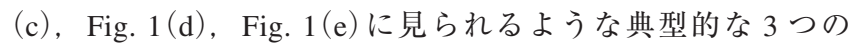
場合を考える.

2: $2 \mathrm{Mg}+\mathrm{Cu} \rightarrow \mathrm{Mg}_{2} \mathrm{Cu}$

6: $2 \mathrm{Mg}_{2} \mathrm{Cu}+3 \mathrm{H}_{2} \rightarrow 3 \mathrm{MgH}_{2}+\mathrm{MgCu}_{2}$

5: $\mathrm{Mg}+\mathrm{H}_{2} \rightarrow \mathrm{MgH}_{2}$

3: $\mathrm{Mg}_{2} \mathrm{Cu}+3 \mathrm{Cu} \rightarrow 2 \mathrm{MgCu}_{2}$

4: $\mathrm{MgCu}_{2}+3 \mathrm{Mg} \rightarrow 2 \mathrm{Mg}_{2} \mathrm{Cu}$

$3 \mathrm{MgH}_{2}+\mathrm{MgCu}_{2} \rightarrow 2 \mathrm{Mg}_{2} \mathrm{Cu}+3 \mathrm{H}_{2}$ $\mathrm{MgH}_{2} \rightarrow \mathrm{Mg}+\mathrm{H}_{2}$

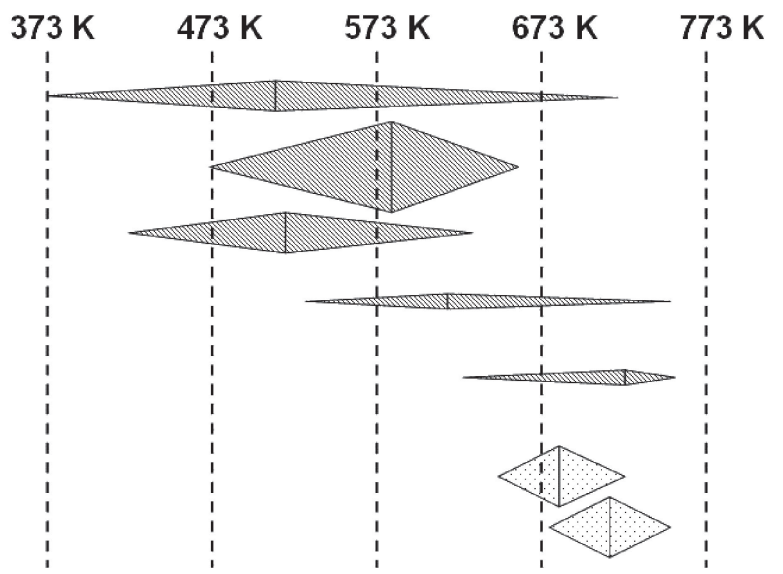

Fig. 7 Schematic diagram of multipath reactions representing the temperature range and intensity of reactions.

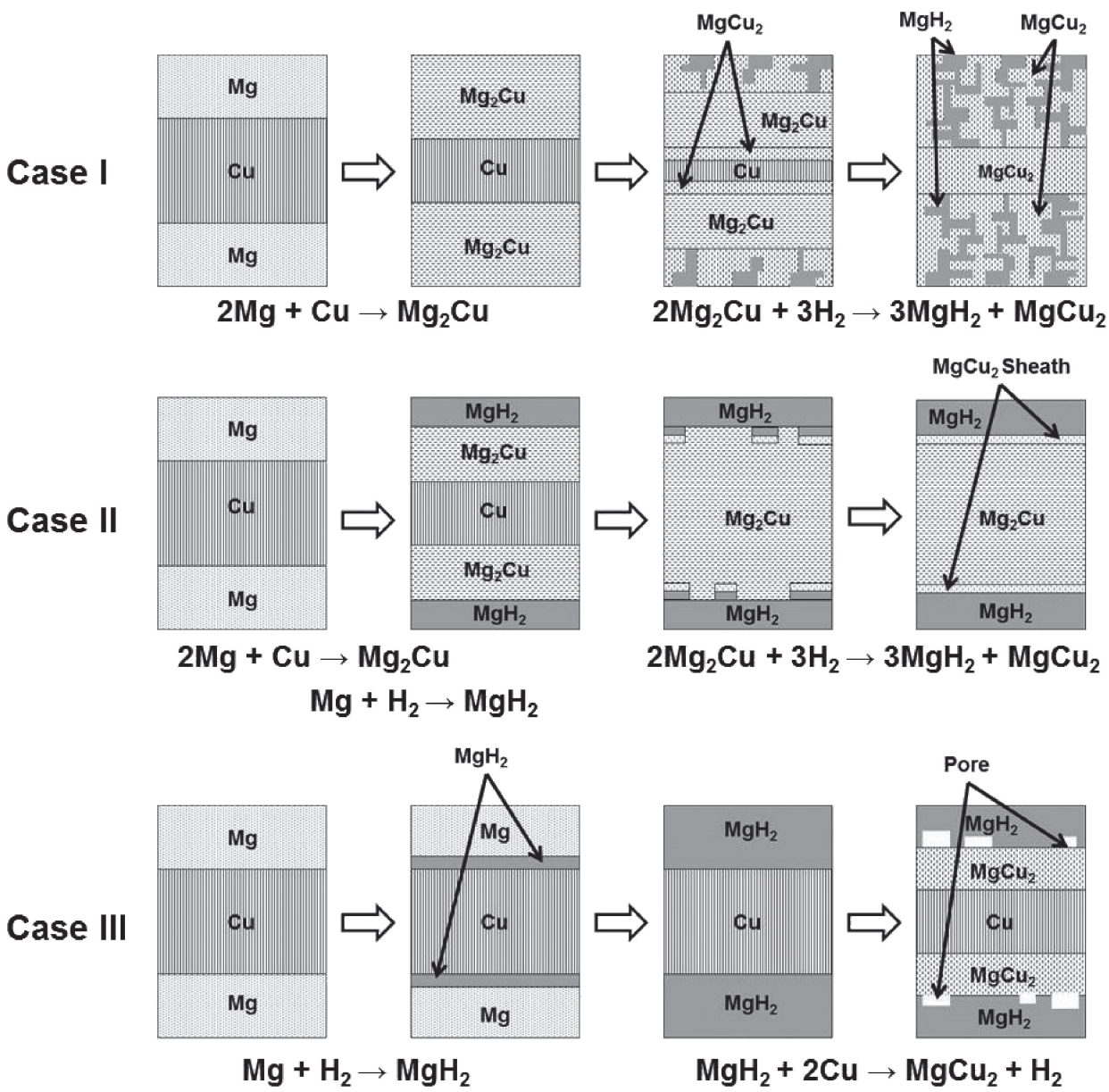

Fig. 8 Schematic models of microstructure formation mechanism through competitive reactions during initial hydrogenation of $\mathrm{Mg} / \mathrm{Cu} \mathrm{SLCs}$. Case I: $\mathrm{MgCu}_{2}$ network type, Case II: $\mathrm{MgCu}_{2}$ sheath type, Case III: $\mathrm{MgCu}_{2}$ layer type. 
Case I では，まず初めに $\mathrm{Mg}_{2} \mathrm{Cu}$ の生成が始まる。そして， $\mathrm{Mg}_{2} \mathrm{Cu}$ が成長し, $\mathrm{Mg}_{2} \mathrm{Cu}$ が $\mathrm{MgH}_{2}+\mathrm{MgCu}_{2}$ に相分離するよ うに水素化し, 初期水素化後は Fig. 1(c)に見られるような $\mathrm{MgH}_{2}$ と共存する開いた $\mathrm{MgCu}_{2}$ 網目構造を形成する。この状 況は, $\mathrm{Mg}_{2} \mathrm{Cu}$ 単相の水素化と同じである27).

Case II では, $\mathrm{Mg}_{2} \mathrm{Cu}$ の形成が初めに始まる。 そして, $\mathrm{Mg}_{2} \mathrm{Cu}$ が成長する. しかしながら, $\mathrm{Mg}_{2} \mathrm{Cu}$ の水素化の前に $\mathrm{Mg}$ の水素化が起こって $\mathrm{MgH}_{2}$ が形成される. $\mathrm{Mg}_{2} \mathrm{Cu}$ の水素 化過程において $\mathrm{Mg}_{2} \mathrm{Cu}$ は $\mathrm{MgH}_{2}+\mathrm{MgCu}_{2}$ に相分離するので, $\mathrm{Mg}_{2} \mathrm{Cu}$ を囲っている $\mathrm{MgH}_{2}$ は, $\mathrm{Mg}_{2} \mathrm{Cu}$ の相分離によって生 成される $\mathrm{MgH}_{2}$ の核形成サイトになり得ると考えられるの で, $\mathrm{Mg}_{2} \mathrm{Cu}$ が水素化して $\mathrm{MgH}_{2}+\mathrm{MgCu}_{2}$ に相分離する時, 先 に $\mathrm{Mg}$ が水素した周りの $\mathrm{MgH}_{2}$ に沿うように $\mathrm{MgH}_{2}$ が生成し, $\mathrm{Mg}_{2} \mathrm{Cu}$ を囲うように $\mathrm{Mg}_{2} \mathrm{Cu}$ の表面に沿って $\mathrm{MgCu}_{2}$ が成長す る。結果として, Fig. 1(d)に見られるような $\mathrm{MgCu}_{2}$ の鞘構 造が形成される. $\mathrm{Mg}_{2} \mathrm{Cu}$ の水素化は, Fig. 1 (d)に見られるよ うに $\mathrm{Mg}_{2} \mathrm{Cu}$ が $\mathrm{MgCu}_{2}$ に完全に囲まれた時に止まると思われ る。このことは, $\mathrm{ARB}$ サイクル 10 回の $\mathrm{Mg} / \mathrm{Cu}$ 超積層体が 水素をゆっくり吸蔵し, ARB サイクル 20 回, 30 回の $\mathrm{Mg}$ / $\mathrm{Cu}$ 超積層体が水素を迅速に吸蔵する36)ことと矛盾しない. 同じような状況は, Fig. 2(b)に見られるようにDSC 測定の 冷却過程で起こっている。 この過程では, $710 \mathrm{~K}$ 近傍で $\mathrm{Mg}$ の水素化が初めに起こり，そして，630 K 近傍で $\mathrm{Mg}_{2} \mathrm{Cu}$ の水 素化が起こる. $\mathrm{Mg}_{2} \mathrm{Cu}$ の水素化ピークが低温側に長いテール を持つことは, この $\mathrm{MgCu}_{2}$ の鞘構造のためであると理解で きる. Fig. 2(c)では, DSC 測定の第二サイクルにおいて, こ の傾向は弱い。 なぜなら, 後で説明するようにDSC 測定の 第一サイクルにおいて Case III が起こると考えられるので, Fig. 2(c)はFig. 2(b) と状況が異なるからである.

Case III では, $\mathrm{Mg}$ の水素化が初めに起こる. そして, 化学 反応式 $\mathrm{MgH}_{2}+2 \mathrm{Cu} \rightarrow \mathrm{MgCu}_{2}+\mathrm{H}_{2}$ に従って $\mathrm{Cu}$ と反応して Fig. 1 (e) に見られるような $\mathrm{MgCu}_{2}$ 層を生成する. この反応
は, $\mathrm{MgCu}_{2}$ の脱水素化反応である. Fig. 1(e)において, $\mathrm{MgCu}_{2}$ 層の近傍にはしばしばポアが存在していることに注意 すべきである。これは，水素放出のためと考えられる，水素 雲囲気下での $\mathrm{MgH}_{2}$ と $\mathrm{Cu}$ の反応は一般には知られていない が, この反応の存在は, 以前の実験で確かめられている27,28). 穏便な条件では $\mathrm{MgCu}_{2}$ は水素を吸蔵しないので, Case III は 避けるべきである。したがって，低温での $\mathrm{Mg}_{2} \mathrm{Cu}$ の成長に とって, $\mathrm{ARB}$ 中に $\mathrm{Mg}$ と $\mathrm{Cu}$ の間に $\mathrm{Mg}_{2} \mathrm{Cu}$ が生成することに より $\mathrm{Mg}$ と $\mathrm{Cu}$ が直接接していないことや，加熱時にそれが 種結晶的な役割を果たして, $\mathrm{Mg}_{2} \mathrm{Cu}$ が速やかに成長する状況 が重要なポイントであると考えられる.

Fig. 4 から, $\mathrm{Mg} / \mathrm{Cu}$ 超積層体中の $\mathrm{Mg}_{2} \mathrm{Cu}$ の体積率は反応 温度と $\mathrm{Mg}+\mathrm{Cu}$ の厚さで制御できることがわかる。また， $\mathrm{Mg}_{2} \mathrm{Cu}$ の水素化が支配的であるためには $\mathrm{Mg}$ 層が薄いことも 重要である. 厚さ $40 \mu \mathrm{m}$ の $\mathrm{Mg}$ 箔と厚さ $10 \mu \mathrm{m}$ の $\mathrm{Cu}$ 箔が元 来より出発原料として使用されているが, 取り扱い上の観点 から, これ以上薄い $\mathrm{Mg}$ 䇴や $\mathrm{Cu}$ 䇴を使うことは適切ではな い.また, Fig. 5 からわかるように, ARB サイクル数 20 回 と 30 回の $\mathrm{Mg} / \mathrm{Cu}$ 超積層体中の $\mathrm{Mg}$ の厚さはほとんど同じで あるので, $\mathrm{ARB}$ サイクル数を増やすことも効果的ではない. ただし，Fig. 9 に見られるように ARB サイクル数 20 回と 30 回の圧延まま $\mathrm{Mg} / \mathrm{Cu}$ 超積層体の微細構造から判断して, $\mathrm{ARB}$ サイクル数を増やすことにより $\mathrm{Mg} / \mathrm{Cu}$ 超積層体の不揃 いで均一性に欠けた品質を改善することはできる。

$\mathrm{Mg} / \mathrm{Cu}$ 超積層体から $\mathrm{Mg}_{2} \mathrm{Cu}$ 相を形成する方法は 2 つある. 1 つは, $\mathrm{Mg} / \mathrm{Cu}$ 超積層体を水素化の後, 脱水素化すること である。もう 1 つは, $\mathrm{Mg} / \mathrm{Cu}$ 超積層体を不活性ガス中で直 接焼鈍することである，後者では，より高温での焼鈍は効 率的ではあるが, 高温では $\mathrm{MgCu}_{2}$ が生成するという久点 がある. また前者では, 水素化・脱水素化法に拉いて, 脱水 素化過程を使うことにより $\left(\mathrm{MgH}_{2}\right.$ 脱水素化により生成した $\mathrm{Mg}$ と未反応の $\mathrm{Cu}$ から $\mathrm{Mg}_{2} \mathrm{Cu}$ が効果的に生成する可能性が
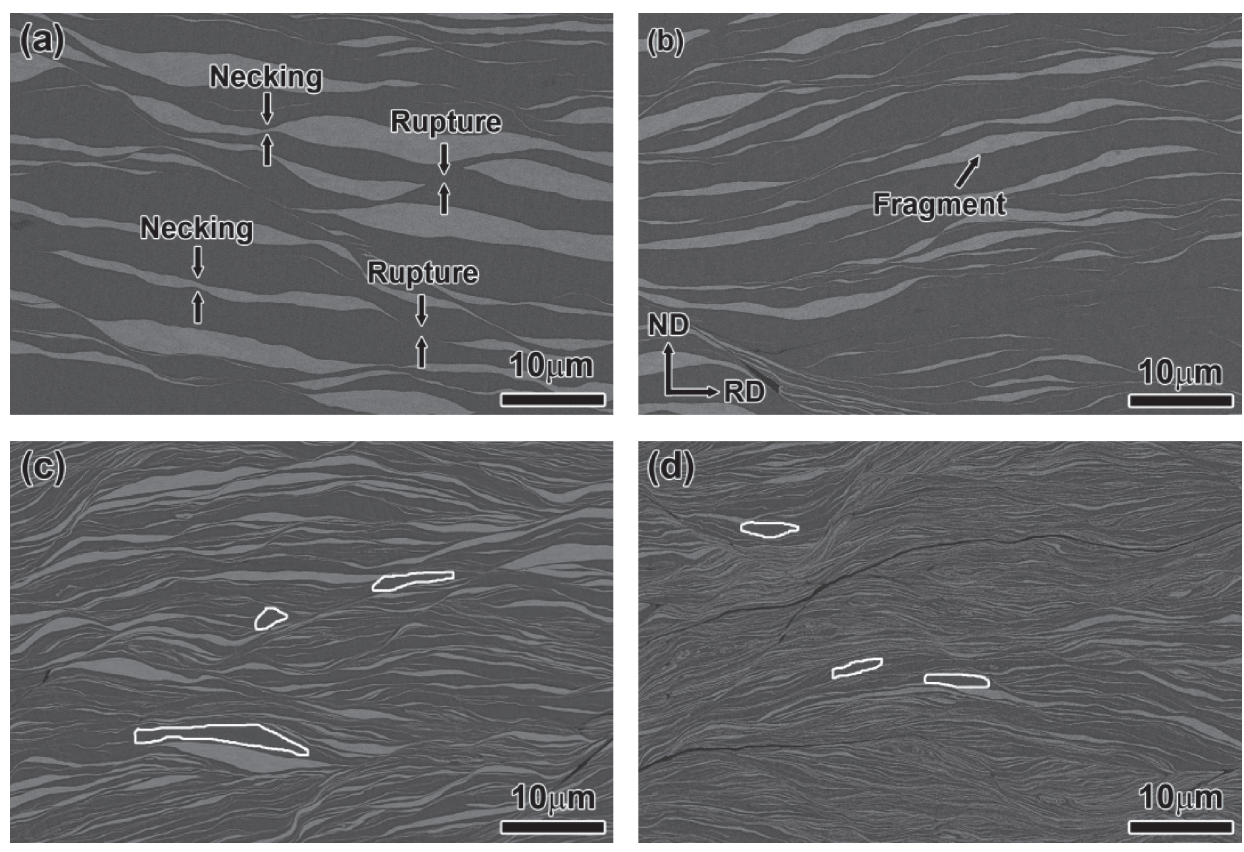

Fig. 9 Backscattered electron images by SEM of as-rolled Mg/Cu SLCs after (a) 5, (b) 10, (c) 20 and (d) 30 ARB cycles. 
ある.この方法のもう 1 つの良い点は, 水素化・脱水素化法 で得られた $\mathrm{Mg}_{2} \mathrm{Cu}$ の結晶粒径が, 水素化-相分解-脱水素再結合 (hydrogen disproportionation desorption recombination, HDDR） ${ }^{43-45)}$ により約 $1 \mu \mathrm{m}$ と比較的小さく，このことが水素 吸蔵速度において効果的であることである. Shao らは12), $673 \mathrm{~K}, 0.1 \mathrm{MPa}$ の $\mathrm{Ar}$ 雲囲気中で $25.2 \mathrm{ks}(7 \mathrm{~h})$ の手頃な条件下 では, 金属ナノ微粒子から純粋な $\mathrm{Mg}_{2} \mathrm{Cu}$ 化合物を得ること は困難であり, $\mathrm{Mg}_{2} \mathrm{Cu}$ 合金を $673 \mathrm{~K}, 4.0 \mathrm{MPa}$ の水素䨌囲気 下で $32.4 \mathrm{ks}(9 \mathrm{~h})$ 加熱して $7.2 \mathrm{ks}(2 \mathrm{~h})$ 真空引きした方が良い結 果であったと指摘している。

我々は, $\mathrm{Mg}_{2} \mathrm{Cu}$ を得るために $\mathrm{Mg} / \mathrm{Cu}$ 超積層体を初期活性 化 $(573 \mathrm{~K}, 3.3 \mathrm{MPa}$ の条件下での水素化と $573 \mathrm{~K}$, 真空の条件 下での脱水素化)した. 水素化と脱水素化を数回繰り返した が, 残留 $\mathrm{Cu}$ は完全にはなくならなかった. しかしながら, $753 \mathrm{~K}$ まで加熱した DSC 測定を 20 回繰り返した後には残留 $\mathrm{Cu}$ は消えた。より高温での水素化と脱水素化がより効果的 であるかもしれない

$\mathrm{ARB}$ のような変形プロセスで作製された金属多層膜は次の 2 つの範疇に分類することができる，1つは，変形プロセス において硬い相の構成層がネッキングを起こしラメラ状に分 断される. その結果, 硬いラメラ相が複合体中に埋め込まれ る.もう 1 つの場合は, 層の厚さがナノスケールに減少する まで，構成層が連続したまま維持されるものである ${ }^{46)}$.

Fig. 9 は, 様々な $\mathrm{ARB}$ サイクル後の $\mathrm{Mg} / \mathrm{Cu}$ 超積層体の RD-ND 面の微細構造を示している. Fig. 9(a)からわかるよ うに，ネッキングと分断は明らかに $\mathrm{Cu}$ 層で観察され， ARB サイクル 5 回以上では, 分断された $\mathrm{Cu}$ が $\mathrm{Mg}$ 母相中に島状 に共存した状態になる. Fig. 9(b)-Fig. 9(d)に見られるよう に $\mathrm{ARB}$ サイクルが進むに伴い, $\mathrm{Cu}$ の分断化も進み, $\mathrm{Cu}$ 断 片が増加して Mg 母相中に微細に分散する. Fig. 9 から判断 して, $\mathrm{Mg} / \mathrm{Cu}$ 超積層体は前者に分類されるように見える.

非類似な金属の同時変形と強さ係数, 歪み硬化指数のよう な流動性や構成相の初期厚さ比の違いのために, ネッキング と破断が硬い相で起きる47). 破断が始まるとき, (白線で囲 まれた) 無断片領域が微細構造中に生成する. Fig. 9(b) から わかるように，無断片領域は ARB サイクル 10 回以降である 程度まで減少する。しかしながら， Cu 断片の分布は依然と して不均一である. Fig. 9(c)や Fig. 9(d)のような Cu 断片の 均一な分布を得るためには, 高い ARB サイクル数を適用す ることが必要である。

一般的に，非類似な金属の同時変形中に，構成相の流動性 の違いに起因して塑性不安定性が生じる。そして, さらなる 変形が硬い相のネッキングと最終的な破断を引き起こす。そ れゆえ，層の連続性を保ったままの多層構造を維持するのは 困難である。上で説明したように，ARB サイクル 20 回また は30 回以降においてさえも, $\mathrm{Mg} / \mathrm{Cu}$ 超積層体の不揃いで均 一性に欠けた品質に起因した，初期水素化中の加熱過程にお ける微細構造形成機構は 3 つある。Case I(網目状 $\mathrm{MgCu}_{2}$ )た けが起こるようにするためには, $\mathrm{Mg} / \mathrm{Cu}$ 超積層体中に微細で 均質・均一な微細組織を得ることが重要である. 上の Fig. 5 について説明したように，この目的のためには 30 回以上の ARB サイクルは非効率であり，流動性を変えることが良い戦
略であると思われる。それゆえ，ARB 中の焼鈍，温間圧延， 超音波圧延などを試す価值があると考えられる.

\section{4. 結 論}

$\mathrm{Mg} / \mathrm{Cu}$ 超積層体中の初期水素化中の競合反応を通じた微 細組織形成機構が解明された。

$\mathrm{Mg} / \mathrm{Cu}$ 超積層体の初期活性化の加熱過程中の微細組織形 成の初期ステージにおいて, $\mathrm{Mg}_{2} \mathrm{Cu}$ の形成 $(\mathrm{Mg}$ と $\mathrm{Cu}$ の合金 化) 抢よびその後の $\mathrm{Mg}_{2} \mathrm{Cu}$ の水素化と $\mathrm{Mg}$ の水素化が競合的 に起こる。

以下に示すように $\mathrm{Mg}$ と $\mathrm{Mg}_{2} \mathrm{Cu}$ の水素化の順番に応じて, 形成機構は，3つのケースに場合分けされる.

Case I : $\mathrm{Mg}_{2} \mathrm{Cu}$ の水素化の後に $\mathrm{Mg}$ の水素化が起こり, 網目 状 $\mathrm{MgCu}_{2}$ が形成される.

Case II : $\mathrm{Mg}_{2} \mathrm{Cu}$ の生成の後, $\mathrm{Mg}_{2} \mathrm{Cu}$ の水素化の前に, $\mathrm{Mg}$ の 水素化が起こり, 鞘状 $\mathrm{MgCu}_{2}$ が形成される.

Case III : $\mathrm{Mg}_{2} \mathrm{Cu}$ の生成の前に $\mathrm{Mg}$ の水素化(5)が起こり, 層 状 $\mathrm{MgCu}_{2}$ が形成される。

Case I(網目状 $\mathrm{MgCu}_{2}$ ) だけが起こるようにするためには, $\mathrm{Mg} / \mathrm{Cu}$ 超積層体中に微細で均質・均一な微細組織を得ること が重要である，ARB 中の焼鈍，温間圧延，超音波圧延などの ように流動性を変化させることが，この目的のために有効な 戦略であると思われる。

この研究は，科研費番号 23560794 と 15K06519 の元で行 われた。著者らは，車谷考介氏，池内秀規氏，西野大爾氏， 林耕生氏の実験補助に対して感謝の意を表する.

文献

1) J.F. Stampfer, Jr., C.E. Holley, Jr. and J.F. Suttle: J. Am. Chem. Soc. 82 (1960) 3504-3508.

2) M. Danaie, C. Mauer, D. Mitlin and J. Huot: Int. J. Hydrogen. Energ. 36 (2011) 3022-3036.

3) G.F. Lima, M.R.M. Triques, C.S. Kiminami, W.J. Botta and A.M. Jorge, Jr.: J. Alloy. Compd. 586 (2014) S405-S408.

4) T. Vegge, L.S. Hedergaad-Jansen, J. Bonde, T.R. Munter and J.K. Nørskov: J. Alloy. Compd. 386 (2005) 1-7.

5) T. Sato, H. Blomqvist and D. Noréus: J. Alloy. Compd. 356-357 (2003) 494-496.

6) P. Selvam, B. Viswanathan, C.S. Swamy and V. Srinivasan: Int. J. Hydrogen Energy 13 (1988) 87-94.

7) N. Hanada, T. Ichikawa, S. Hino and H. Fujii: J. Alloy. Compd. 420 (2006) $46-49$

8) S. Isobe, A. Ono, H. Yao, Y. Wang, N. Hashimoto and S. Ohnuki: Appl. Phys. Lett. 96 (2010) 223109.

9) T. Ma, S. Isobe, E. Morita, Y. Wang, N. Hashimoto, S. Ohnuki, T. Kimura, T. Ichikawa and Y. Kojima: Int. J. Hydrogen Energy 36 (2011) 12319-12323.

10) L.-P. Ma, P. Wang and H.-M. Chen: Int. J. Hydrogen Energy 35 (2010) 3046-3050.

11) J. Mao, Z. Guo, X. Yu, H. Liu, Z. Wu and J. Ni: Int. J. Hydrogen Energy 35 (2010) 4569-4575.

12) H. Shao, Y. Wang, H. Xu and X. Li: J. Solid State Chem. 178 (2005) 2211-2217.

13) M. Au: Mater. Sci. Eng. B 117 (2005) 37-44.

14） L. Zaluski, A. Zalusuka and J.O. Ström-Olsen: J. Alloy. Compd. 253254 (1997) 70-79.

15) T. Aizawa, T. Kuji and H. Nakano: J. Alloy. Compd. 291 (1999) 248 253

16) S. Ruggeri, C. Lenain, L. Roué, G. Liang, J. Huot and R. Schulz: J. Alloy. Compd. 339 (2002) 195-201. 
17) S. Pedneault, J. Huot and L. Roué: J. Power Sources 185 (2008) 566569.

18) T.T. Ueda, M. Tsukahara, Y. Kamiya and S. Kikuchi: J. Alloy. Compd. 386 (2005) 253-257.

19) K. Tanaka, H.T. Takeshita, K. Kurumatani, H. Miyamura and S. Kikuchi: J. Alloy. Compd. 580 (2013) S222-S225.

20) K. Tanaka, N. Takeichi, H. Tanaka, N. Kuriyama, T.T. Ueda, M. Tsukahara, H. Miyamura and S. Kikuchi: J. Mater. Sci. 43 (2008) 3812-3816.

21) N. Takeichi, K. Tanaka, H. Tanaka, T.T. Ueda, Y. Kamiya, M. Tsukahara, H. Miyamura and S. Kikuchi: J. Alloy. Compd. 446-447 (2007) 543-548.

22) J. Dufour and J. Huot: J. Alloy. Compd. 439 (2007) L5-L7.

23) J. Dufour and J. Huot: J. Alloy. Compd. 446-447 (2007) 147-151.

24) K. Suganuma, H. Miyamura, S. Kikuchi, N. Takeichi, K. Tanaka, H. Tanaka, N. Kuriyama, T.T. Ueda and M. Tsukahara: Adv. Mater. Res. 26-28 (2007) 857-860.

25) R. Mori, H. Miyamura, S. Kikuchi, K. Tanaka, N. Takeichi, H. Tanaka, N. Kuriyama, T.T. Ueda and M. Tsukahara: Mater. Sci. Forum 561-565 (2007) 1609-1612.

26) J.J. Reilly and R.H. Wiswall: Inorg. Chem. 6 (1967) 2220-2223.

27) K. Tanaka, K. Shibata, K. Kurumatani, S. Ikeuchi, S. Kikuchi, R. Kondo and H.T. Takeshita: J. Alloy. Compd. 645 (2015) S72-S75.

28) K. Shibata, K. Tanaka, K. Kurumatani, Y. Nishida, R. Kondo and H.T. Takeshita: Mater. Trans. 56 (2015) 785-789.

29) K. Tanaka, H.T. Takeshita, H. Shin, K. Kurumatani, T. Kiyobayashi, N. Takeichi, H. Miyamura and S. Kikuchi: Mater. Trans. 55 (2014) 1122-1128.

30) J. Huot, N.Y. Skryabina and D. Fruchart: Metals 2 (2012) 329-343.

31) K. Nonaka, T. Sakazawa and H. Nakajima: Mater. Trans. JIM 36 (1995) 1463-1466.
32) J. Dai, B. Jian, J. Zhang, Q. Yang, Z. Jian, H. Dong and F. Pan: J. Phase Equilibria Diffus. 36 (2015) 613-619.

33) Q.Z. Hong and F.M. d'Heurle: J. Appl. Phys. 72 (1992) 4036-4040.

34) B. Arcot, S.P. Murarka, L.A. Clevenger, Q.Z. Hong, W. Ziegler and J.M.E. Harper: J. Appl. Phys. 76 (1994) 5161-5170.

$35)$ K. Tanaka, D. Nishino, K. Hayashi, S. Ikeuchi, R. Kondo and H.T. Takeshita: Int. J. Hydrogen Energy 42 (2017) 22502-22510.

36) K. Tanaka, D. Nishino, R. Kondo and H.T. Takeshita: IOP Conf. Ser. Mater. Sci. Eng. 375 (2018) 012032.

37) B.B. Straumal, A.A. Mazilkin, B. Baretzky, G. Schütz, E. Rabkin and R.Z. Valiev: Mater. Trans. 53 (2012) 63-71.

38) T. Fujita, Z. Horita and T.G. Langdon: Mater. Sci. Eng. A 371 (2004) 241-250.

39) K. Edalati, S. Toh, M. Watanabe and Z. Horita: Scr. Mater. 66 (2012) 386-389.

40) K. Oh-ishi, K. Edalati, H.P. Kim, K. Hono and Z. Horita: Acta Mater. 61 (2013) 3482-3489.

41) S.V. Divinski, G. Reglitz, H. Rösner, Y. Estrin and G. Wilde: Acta Mater. 59 (2011) 1974-1985.

42) K. Tanaka, R. Kondo and H.T. Takeshita: Mater. Sci. Forum 941 (2018) 1927-1932.

43) H. Takamura, T. Miyashita, A. Kamegawa and M. Okada: J. Alloy. Compd. 356-357 (2003) 804-808.

44) T. Miyazawa, Y. Kobayashi, A. Kamegawa, H. Takamura and M. Okada: Mater. Trans. 45 (2004) 384-387.

45) A. Kamegawa, T. Funayama, J. Takahashi, H. Takamura and M. Okada: Mater. Trans. 46 (2005) 2449-2453.

46) J.-M. Lee, B.-R. Lee and S.-K. Kang: Mater. Sci. Eng. A 406 (2005) 95-101.

47) M. Reihanian and M. Naseri: Mater. Des. 89 (2016) 1213-1222. 